\title{
The Next Twenty-Five Years in the Development of Chinese Libraries
}

$\mathrm{T}$

HAT the library occupies an integral part in the future development of the Chinese nation has been recognized by many of the country's progressive leaders. But very few realize that underlying its organization and development an over-all policy is of paramount importance. We cannot deny that in the past quarter of a century, with a few exceptions, library development in China has been largely a sporadic, spur-of-the-moment phenomenon. Some are even accidental, attributable to personality or circumstance rather than to careful and systematic planning or as an answer to actual needs. They frequently have been. subordinated to political exigencies and vicissitudes.

In offering a blueprint for the development of Chinese libraries in the next twenty-five years, we must have first of all a clear and accurate objective for the different types of libraries in China as well as an intelligent understanding of their relative position in the fabric of national life. The plan should be practical and yet flexible, not high-sounding and unattainable; it should be consistent and coherent, not haphazard, piecemeal, and lopsided.

In the past many people have emphasized only the immediate and utilitarian functions of a library; that is, they have regarded the library solely as a place for information and research. They seldom envisage the library as an agency for continuous education, for esthetic appreciation, and for wholesome recreation. On the part of the clientele, the library is viewed with apprehension and frigidity, a place to resort to only in cases of dire need. As to the library itself, it places too much emphasis on the preservation rather than the profitable use of its contents. To place library planning on a sound footing, all these anomalous notions regarding the functions of a library should be dispelled.

With a proper perspective, there should be under the Ministry of Education a national library commission to map general plans and policies of library development and to have coverage for the entire nation. This commission, temporary in nature, should be composed of qualified and experienced librarians as well as competent educators and public administrators, whose functions would be as follows:

I. The determination of objectives for the various types of libraries needed in the country

2. The inventory of present war-depleted facilities and needs in the light of these goals

3. The formulation of an over-all plan and policy to meet these needs

4. The progressive execution of the plan and allocation of responsibility to the proper agencies.

Once the above functions have been carried out, a permanent library board, under the Ministry of Education and headed by a competent, professional librarian, should be appointed. This would be a permanent organization whose function should be similar to that of the Library Service Division of the U.S. Office of Education. It should be charged with the 
duties of fact-finding and research, of guiding and encouraging the development of local services, and of promoting better cooperation and coordination among libraries. It should be given status and financial support commensurate with its importance as the national headquarters for library matters. This board also should formulate and recommend adequate legislation for the organization, development, and maintenance of libraries on a national scale.

Parallel with the official library board is the nonofficial entity, namely, the Library Association of China. This organization was founded over twenty years ago. Owing to lack of adequate financial support, it has not been as active as it should have been. Being a private institution, to function best it must be endowed with sufficient funds. It should work in close cooperation with the official board, supplementing it but not duplicating the work done by it.

As to a national system of libraries the following may be suggested:

x. National libraries

2. Provincial libraries

3. Municipal or district libraries

4. Special libraries

5. College and university libraries

6. School libraries

\section{Functions of National Libraries}

The national libraries should function along the same line as the Library of Congress in the United States, or the British Museum for Great Britain, and should be financed from the national coffers. They should be entrusted with the task of preserving the cultural heritage of the nation, assembling old and rare printed and written records and, by means of photoduplication, making them available to the reading public. Catholic in interest and all-embracing in content, they should offer sanctuary to all facets of opinion and all aspects of knowledge. Though primarily of a reference nature, they should also assemble representative collections of books in foreign languages so that scholars of the nation may be able to keep abreast of developments in various lines of human endeavor in other parts of the world. In addition to being the national storehouse of knowledge, such essential work as union catalogs, printed catalog cards for general distribution, copyright registration, maintenance of a center for bibliographical information, international exchange, and other related functions should be assigned to the national libraries. They should serve as a clearinghouse of bibliographical information for other libraries, to furnish advice and assistance wherever needed.

It is essential that each function should be entrusted to the particular library which is best suited for that special type of work and which, in the light of achievements of the past, is best qualified for such assignments. Lines of specialization should be agreed upon by the national libraries. In these, as in other functions of the libraries, unnecessary and wasteful duplication should be avoided.

\section{Provincial Libraries}

The provincial libraries serving the various provinces should correspond roughly to the state libraries and state library agencies in this country. They should be effective agencies for adult education, disseminating basic reading material for the enlightenment of the people. They should guide, encourage, and assist the development of library service within their provinces. By use of extension work and mobile units they should be able to reach all points within their territory.

The municipal or district libraries, public in nature and administered by the local governments, should be supported primarily 
by appropriations from the local governments, with possible grants-in-aid from both the provincial and central governments. If possible, a certain percentage of the total income of each local government unit should be designated for this purpose. Judging by the present number of such governmental units in China, there should be at least three thousand public libraries. If properly integrated with the mass education movement, they should help materially in combating illiteracy and in promoting true and useful citizenship. Within the areas of the municipal and district libraries, branch reading rooms or stations could be set up in public or semipublic buildings like ancestral halls and temples.

Greater stress, perhaps, should be placed on this type of library service, for it is the most basic and effective medium for the diffusion of knowledge to the masses. Only libraries of this kind can reach the greatest number of the populace, constituting as they do the bulk of Chinese libraries.

Standards and grades for the local public libraries should be set up by each province. There should be under the provincial library or government a board whose function it is to assist, advise, supervise, and coordinate the activities of the various local libraries within the province. The general level of their services should be adequate and suited to local community needs. In short, this province-wide system of library service is per se an indispensable adjunct to the educational program that must figure prominently in postwar China if she is to assume her proper place among nations.

\section{Special Libraries}

Not only are general libraries needed, but special engineering, business, industrial, and other technical libraries will be in great demand during the period of reconstruction and rehabilitation. As yet there are very few special libraries in China, but their need will be increasingly apparent in the near future. Industrial and commercial libraries, for instance, would be extremely useful in such centers as Shanghai, Hankow, Tientsin, and other large cities.

College and university libraries, as well as school libraries, should be maintained according to the needs of the individual institutions. They should be provided with basic as well as supplementary collections for the use of both faculty and students. They should be made accessible to the general public as well.

It will be futile for our purpose here, perhaps, to suggest any quantitative standards for library coverage in China, for they will be governed by a number of such important factors as general political conditions, financial ability, educational facilities, and the degree of literacy among the masses. But with a carefully conceived program, a fine network of libraries throughout the whole country can do a great deal to advance the well-being of the people. To execute this plan efficiently there should be a competent personnel.

In the past library training in China has been much neglected. Very important posts sometimes have been entrusted to novices who regard their offices as nothing more than sinecures. Many people still entertain the erroneous notion that the library profession can be undertaken by anybody, that adequate training and experience are not really necessary. To correct such a deplorable attitude, it is essential that the public be indoctrinated with the importance of the duties of a librarian toward his reading public. There should be a sufficient number of library schools of high quality to train an adequate supply of personnel for the profession. Such schools should be affiliated with universities of recognized standing and not with any li- 
braries, however strong they might be. Experience in the United States has shown that the former approach is more ideal for the solution of the training program. The graduates of the schools of library science should be on an equal footing with those of other professional schools.

\section{Salary Situation}

In the past more than a few competent librarians in China have left the profession for more lucrative positions. This question of remuneration, as well as that of prestige, is not exaggerated, for as a rule competent librarians in China are not receiving salaries commensurate with their responsibility. It behooves the library schools to produce wellqualified men and women to whom society should then accord due recognition. Competent, efficient, and enterprising young people should be recruited for the library profession - a profession that should be of growing importance, interest, and respect in China. At government expense, promising young people should be selected by competitive examination for advanced study and training in Western countries, especially in the United States.

As to technical processes, a great deal remains to be done. For instance, as yet we do not have a unified, comprehensive classification scheme for Chinese books; we have instead dozens of schemes of questionable merit, thus causing considerable confusion and inconvenience. To remedy this situation, a competent committee of experts should be appointed to study the subject and to agree on basic principles. Certain subjects should then be assigned to particular libraries which specialize in these fields. After the different classes have been fully tried and developed, the committee should assemble and edit them into a composite whole for uniform adoption by libraries.

Related to classification are cataloging practices, filing methods, and author numbers, to name only three of the most important processes in which cooperative effort is needed. To facilitate interlibrary loan and to achieve greater efficiency, all of these should be standardized and unified. As a liaison office, the Library Association of China can help to attain these goals.

In their postwar development no libraries should take upon themselves the censorship of reading matter nor should they be partisans in any issues. In new China the librarian's function is to suggest, not to decide for his readers; to advise and not to arbitrate on controversial matters. For these reasons, the book collections should be of sufficient size and of good quality.

\section{Services Should Be Integrated}

Above all, we should bear in mind that the library is by no means an isolated institution functioning by itself; it should integrate its services with the work of other social and cultural agencies. The recent movement for larger units of service in the United States can be profitably adopted in China. The pooling of resources and administration through centralization are practices that can be introduced in China. Smaller libraries, without losing their essential autonomy, can be grouped into effective service areas.

Throughout this tentative and rather general blueprint for Chinese libraries, I have emphasized, at the risk of redundancy, the need for cooperation and integration among Chinese libraries. A tremendous amount of work awaits us: the restoration of war-devastated libraries, the expansion of other libraries, and the planning of new services. As we may well expect, financial resources for library purposes necessarily will be limited. To obtain maximum results with limited funds, careful study and concerted effort will be most imperative. 